\title{
Hereditary Benign Intraepithelial Dyskeratosis
}

National Cancer Institute

\section{Source}

National Cancer Institute. Hereditary Benign Intraepithelial Dyskeratosis. NCI Thesaurus. Code C3940.

A rare genetic disorder with an autosomal dominant pattern of inheritance with variable penetrance. It was initially described among Native Americans belonging to the HaliwaSaponi tribe of northeastern North Carolina. It is caused by a duplication of chromosomal DNA at 4q35. Clinical signs present in early childhood and include asymptomatic plaques of the epibulbar conjunctivae and oral mucosa. Clinical progression of the plaques to malignancy has not been reported. 